\title{
LSD1-a pivotal epigenetic regulator of brown and beige fat differentiation and homeostasis
}

\author{
Jean Z. Lin and Stephen R. Farmer \\ Department of Biochemistry, Boston University School of Medicine, Boston, Massachusetts 02118, USA
}

In this issue of Genes \& Development, Zeng and colleagues (pp. 1822-1836) identify lysine-specific demethylase 1 (LSD1) as a pivotal regulator of whole-body energy expenditure by controlling the oxidative and thermogenic activity of brown adipose tissue (BAT). They show that LSD1 interacts with PRDM16 to repress select white adipose tissue (WAT) genes but also represses hydroxysteroid 11- $\beta$-dehydrogenase 1 (HSD11B1) independently of PRDM16 to prevent production of glucocorticoids that impair BAT functions. Their study provides important insight into epigenetic mechanisms regulating the function of BAT.

Obesity is an accelerating world epidemic and a leading cause of the increased incidence of diabetes, hyperlipidemia, and cardiovascular disease. Excess calories trigger the storage of triglycerides and the rapid expansion of white adipose tissue (WAT), leading to inflammation and insulin resistance. On the other hand, brown adipose tissue (BAT) burns fat and glucose to generate heat through a process of nonshivering adaptive thermogenesis. Numerous groups have shown the ability to induce brown-like adipocytes in white fat through cold and $\beta$-adrenergic stimulation, often referred to as "browning" or "beiging." The induction and activation of beige adipocytes in mice has been shown to enhance energy expenditure, resist diet-induced obesity, and improve insulin sensitivity. Furthermore, the presence of brown and beige adipocytes in humans is correlated with leanness and resistance to obesity. The activation of brown/beige fat appears to be capable of defending against metabolic disease and may have profound pharmacological potential.

There is great interest in understanding the mechanisms regulating the formation and function of brown and beige adipose, with the goal of controlling energy expenditure to combat obesity. Several groups have identified regulatory factors that control the differentiation of

[Keywords: LSD1; PRDM16; HSD11B1; brown adipose tissue;

thermogenesis; mitochondria]

Corresponding authors: sfarmer@bu.edu, jeanlin@bu.edu

Article is online at http://www.genesdev.org/cgi/doi/10.1101/gad.288720.

116. brown and beige fat cells. In particular, PRDM16, a key transcriptional coregulator, has been shown to control this process through the induction of BAT-specific genes and repression of select WAT genes most abundantly expressed in visceral WAT (Seale et al. 2007; Kajimura et al. 2008). In this issue of Genes \& Development, Zeng et al. (2016) demonstrate that lysine-specific demethylase 1 (LSD1) demethylates H3K4 at genomic loci near WATspecific genes in brown adipocytes by interacting and colocalizing with PRDM16 (Zeng et al. 2016). They further show that LSD1 acts independently of PRDM16 to repress hydroxysteroid 11- $\beta$-dehydrogenase isozyme 1 (HSD11B1) and prevent the production of anti-thermogenic glucocorticoids (GC). A recent study by Sambeat et al. (2016) showed that LSD1 also interacts with Zfp516 and activates BAT-specific genes by demethylation of H3K9. These epigenetic mechanisms control the development and metabolic plasticity of brown and beige fat, and understanding them may lead to the development of therapeutics to control energy expenditure and combat obesity. This outlook aims to address the importance of epigenetic regulation in brown and beige fat function and cell differentiation.

Histone demethylation plays an important role in the regulation of cellular processes essential to energy homeostasis and cell differentiation. Chromatin immunoprecipitation (ChIP) sequencing (ChIP-seq) analysis of histone modifications has shown that distinct chromatin marks exist in brown and white fat. Zeng et al. (2016) showed that PRDM16 association with LSD1, a monohistone and dihistone demethylase, promotes nonshivering thermogenesis by demethylating H3K4 and repressing WATselective genes. They further demonstrated the importance of repressing select genes in establishing the energy-expending character of brown and beige adipocytes and the role played by LSD1 in this mechanism. They demonstrate that adipose-specific deletion of LSD1 elevates WAT-selective gene expression, increases fat mass,

(C) 2016 Lin and Farmer This article is distributed exclusively by Cold Spring Harbor Laboratory Press for the first six months after the full-issue publication date (see http://genesdev.cshlp.org/site/misc/terms.xhtml). After six months, it is available under a Creative Commons License (Attribution-NonCommercial 4.0 International), as described at http:// creativecommons.org/licenses/by-nc/4.0/. 
and reduces energy expenditure. Analogously, PRDM16 can also interact with euchromatic histone lysine $\mathrm{N}$ methyltransferase 1 (EHMT1) to methylate H3K9 and repress WAT genes (Ohno et al. 2013; Harms et al. 2014). Both studies showed that PRDM16 is instrumental in the recruitment of histone modifiers to edit epigenetic marks that determine the brown and beige phenotype. However, the mechanism by which PRDM16 recruits LSD1 or EHMT1 to provide distinct histone modifications within the same WAT gene loci is not known. Given that PRDM16 repression is dependent on transcriptional corepressors such as CtBP1 and CtBP2 (Kajimura et al. 2008), it is likely that these corepressor partners dictate the differential recruitment of the histone modifiers. Moreover, transcription factors that direct PRDM16 to WAT promoters and enhancers are not known. PPAR $\gamma$ is a prospective candidate, since it is known to stabilize PRDM16 and likely facilitates repression (Ohno et al. 2012). Additionally, earlier studies demonstrated that repression of select WAT genes involves recruitment of CtBPs to C/EBPa docked on the corresponding promoters during PPAR $\gamma$-activated beige adipocyte formation (Vernochet et al. 2009). It is likely that PRDM16 is also recruited to these C/EBPa transcriptional repressor complexes.

LSD1 was initially identified in a transcriptional corepressor complex and later found to associate with nuclear receptors, acting as a coactivator and mediating demethylation of H3K9. Studies by Sambeat et al. (2016) demonstrated that LSD1 interacts with Zfp516 to activate UCP1 and other BAT genes. Similar to the work of Zeng et al. (2016), Sambeat et al. (2016) showed that LSD1 ablation in brown fat resulted in impaired BAT development, increased fat mass, and decreased energy expenditure. A previous report demonstrated that Zfp516 interacts with PRDM16, suggesting that LSD1 forms a transcriptional complex to demethylate H3K9 (Dempersmier et al. 2015). While LSD1 appears to be a broadly specific demethylase, its ability to selectively demethylate H3K9 on BAT loci and H3K4 on WAT loci suggests that gene selectivity is likely mediated via interactions with distinct
DNA-binding transcription factors. In fact, earlier studies demonstrated that the cold-mediated increase of oxidative phosphorylation and mitochondrial biogenesis is mediated through LSD1 interaction with Nrf1 (Duteil et al. 2014). The ability to simultaneously repress WAT-selective genes and activate BAT genes by the removal of histone methyl marks suggests that LSD1 is a pivotal hub in ensuring dynamic changes in global gene expression required for the development of thermogenic adipose tissue but also in regulating energy expenditure in the mature brown and beige adipocytes.

LSD1 can also function through PRDM16-independent pathways to regulate cellular processes in energy regulation. LSD1 deletion in adipose tissue had a more pronounced metabolic phenotype compared with PRDM16deficient mice. In fact, Zeng et al. (2016) showed that LSD1 represses glucocorticoid-activating enzyme HSD11B1 independently of PRDM16. The deletion of HSD11B1 in adipose-specific LSD1 knockout mice restores energy-expending functions in brown adipocytes, suggesting that increased HSD11B1 expression and elevated GC levels are major contributors to BAT dysfunction in LSD1 knockout mice. Consistent with this, HSD11B1 overexpression has been shown to suppress brown adipocyte function, while HSD11B1 inhibition elevates cellular respiration (Liu et al. 2013). Interestingly, PPAR $\gamma$ activation is known to repress HSD11B1 expression, and the beneficial effects of PPAR $\gamma$ agonism have been attributed to HSD11B1 repression (Berger et al. 2001). These additional layers of regulation suggest that LSD1 has numerous transcription factor partners by which it coordinates the intricate epigenetic modifications in brown and beige adipocyte differentiation and function (Fig. 1).

Histone demethylation by LSD1 appears to be fundamental in regulating the cellular differentiation of brown and beige adipocytes and in activating BAT genes while repressing select WAT genes. Additionally, LSD1 regulates cellular processes that include GC activation, oxidative phosphorylation, and mitochondrial biogenesis.

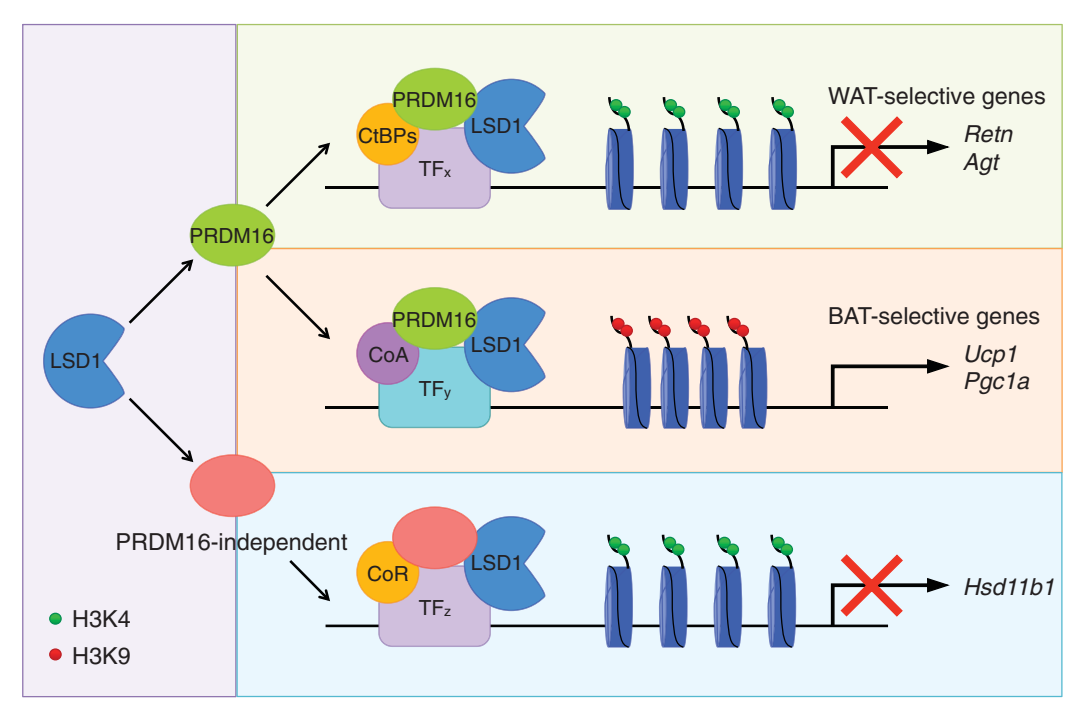

Figure 1. LSD1 demethylates epigenetic modifications to regulate brown and beige differentiation and energy homeostasis. (Top) LSD1 interacts with PRDM16, docks on select transcription factors (TFx; such as C/EBPa), demethylates H3K4, and represses WAT-selective genes. (Middle) LSD1 interacting with PRDM16 can dock on other transcription factors (TFy; such as Zfp516 and possibly Nrf1) to demethylate H3K9 and activate BAT-selective genes. (Bottom) LSD1 represses HSD11B1 independently of PRDM16 by interacting with its corepressor (CoR) partners (such as CoREST). 
Recently, the LSD1+8a isoform has been shown to lack H3K4 demethylation activity while demethylating H3K9 to activate neuronal development (Laurent et al. 2015), suggesting that alternative LSD1 splicing may provide a mechanism for regulating the enzymes' dual-substrate specificity. In conclusion, LSD1 is apparently a central hub that is capable of interacting with various transcription factors and orchestrating histone demethylation. Thus, a better understanding of LSD1 and its regulation of histone modifications would seem to be of great interest, possibly leading to new therapeutic strategies to treat obesity.

\section{Acknowledgments}

S.R.F. and J.Z.L. are supported by National Institutes of Health grants T32DK007201 to J.Z.L, and DK098830 and DK102199 to S.R.F.

\section{References}

Berger I, Tanen M, Elbrecht A, Hermanowski-Vosatka A, Moller DE, Wright SD, Thieringer R. 2001. Peroxisome proliferatoractivated receptor- $\gamma$ ligands inhibit adipocyte $11 \beta$-hydroxysteroid dehydrogenase type 1 expression and activity. I Biol Chem 276: 12629-12635.

Dempersmier J, Sambeat A, Gulyaeva O, Paul SM, Hudak CS, Raposo HF, Kwan HY, Kang C, Wong RH, Sul HS. 2015. Cold-inducible Zfp516 activates UCP1 transcription to promote browning of white fat and development of brown fat. Mol Cell 57: 235-246.

Duteil D, Metzger E, Willmann D, Karagianni P, Friedrichs N, Greschik H, Günther T, Buettner R, Talianidis I, Metzger D, et al. 2014. LSD1 promotes oxidative metabolism of white adipose tissue. Nat Commun 5: 4093.

Harms MJ, Ishibashi J, Wang W, Lim HW, Goyama S, Sato T, Kurokawa M, Won KJ, Seale P. 2014. Prdm16 is required for the maintenance of brown adipocyte identity and function in adult mice. Cell Metab 19: 593-604.

Kajimura S, Seale P, Tomaru T, Erdjument-Bromage H, Cooper MP, Ruas JL, Chin S, Tempst P, Lazar MA, Spiegelman BM. 2008. Regulation of the brown and white fat gene programs through a PRDM16/CtBP transcriptional complex. Genes Dev 22: 1397-1409.

Laurent B, Ruitu L, Murn J, Hempel K, Ferrao R, Xiang Y, Liu S, Garcia BA, Wu H, Wu F, et al. 2015. A specific LSD1/ KDM1A isoform regulates neuronal differentiation through H3K9 demethylation. Mol Cell 57: 957-970.

Liu J, Kong X, Wang L, Qi H, Di W, Zhang X, Wu L, Chen X, Yu J, Zha J, et al. 2013. Essential roles of $11 \beta-H S D 1$ in regulating brown adipocyte function. J Mol Endocrinol 50: 103-113.

Ohno H, Shinoda K, Spiegelman BM, Kajimura S. 2012. PPAR $\gamma$ agonists induce a white-to-brown fat conversion through stabilization of PRDM16 protein. Cell Metab 15: 395-404.

Ohno H, Shinoda K, Ohyama K, Sharp LZ, Kajimura S. 2013. EHMT1 controls brown adipose cell fate and thermogenesis through the PRDM16 complex. Nature 504: 163-167.

Sambeat A, Gulyaeva O, Dempersmier J, Tharp KM, Stahl A, Paul SM, Sul HS. 2016. LSD1 interacts with Zfp516 to promote UCP1 transcription and brown fat program. Cell Rep 15: 2536-2549.

Seale P, Kajimura S, Yang W, Chin S, Rohas LM, Uldry M, Tavernier G, Langin D, Spiegelman BM. 2007. Transcriptional control of brown fat determination by PRDM16. Cell Metab 6: $38-54$.

Vernochet C, Peres SB, Davis KE, McDonald ME, Qiang L, Wang H, Scherer PE, Farmer SR. 2009. C/EBPa and the corepressors $\mathrm{CtBP} 1$ and $\mathrm{CtBP} 2$ regulate repression of select visceral white adipose genes during induction of the brown phenotype in white adipocytes by peroxisome proliferator-activated receptor $\gamma$ agonists. Mol Cell Biol 29: 4714-4728.

Zeng X, Jedrychowski MP, Chen Y, Serag S, Lavery GG, Gygi SP, Spiegelman BM. 2016. Lysine-specific demethylase 1 promotes brown adipose tissue thermogenesis via repressing glucocorticoid activation. Genes Dev (this issue). doi: 10.1101/ gad.285312.116. 


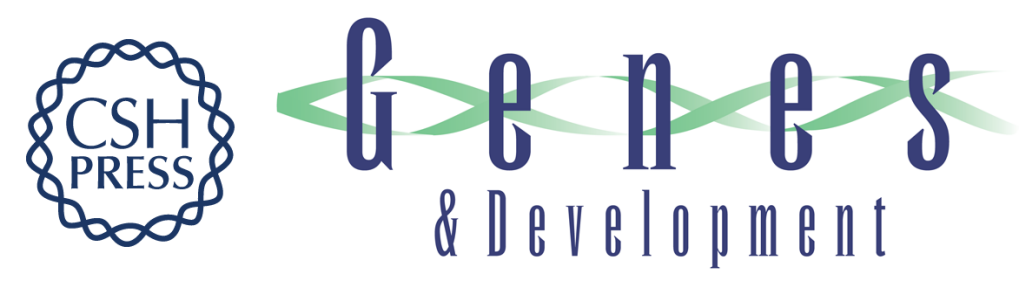

\section{LSD1--a pivotal epigenetic regulator of brown and beige fat differentiation and homeostasis}

Jean Z. Lin and Stephen R. Farmer

Genes Dev. 2016, 30:

Access the most recent version at doi:10.1101/gad.288720.116

Related Content Lysine-specific demethylase 1 promotes brown adipose tissue thermogenesis via repressing glucocorticoid activation

Xing Zeng, Mark P. Jedrychowski, Yi Chen, et al.

Genes Dev. August , 2016 30: 1822-1836

References This article cites 13 articles, 5 of which can be accessed free at:

http://genesdev.cshlp.org/content/30/16/1793.full.html\#ref-list-1

Articles cited in:

http://genesdev.cshlp.org/content/30/16/1793.full.html\#related-urls

Creative This article is distributed exclusively by Cold Spring Harbor Laboratory Press for the first

Commons

License

six months after the full-issue publication date (see

http://genesdev.cshlp.org/site/misc/terms.xhtml). After six months, it is available under a Creative Commons License (Attribution-NonCommercial 4.0 International), as described at http://creativecommons.org/licenses/by-nc/4.0/.

Email Alerting Receive free email alerts when new articles cite this article - sign up in the box at the top

Service right corner of the article or click here.

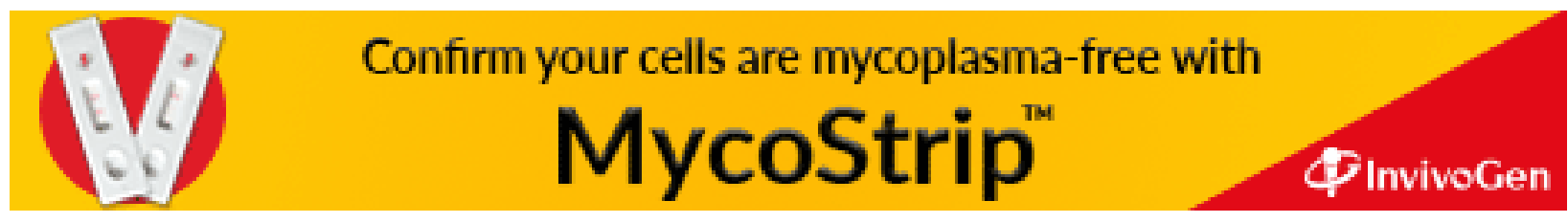

